\title{
世界経済の統合と分解に対する \\ アメリカの政策
}

\section{学習院大学 渡 部 福太郎}

1 、湾岸戦争を契機として「新しい国際秩序の確立」といらことがさかんにい われるよらになったが，その意味するところは暧昧である。半世紀近くのあい だ，国際経済は二極体制のもとにあった。しかし，「東」の社会主義圏の崩壊に より，アメリカのみが超大国として残り，二極体制は必然的にアメリカを主役 とする一極体制となってしまった。そして，もし，新しい国際秩序といらもの があれば，その自体こそがまさに新しい国際秩序を意味することになる。

〔注〕二極体制のもとで秩序は崩壊したため,

1)「東」の旧社会主義では, 民族・宗教対立をこえたイデオロギーの力（その背後に 軍事力）はまったく弱まってしまった。

2)「東」におけるソ連のもとで強制された“協調グーム” は消学て，いまや，民族主 義の紛争・衝突が扣きている。

3）西側でも，アメリカの覇権のもとに，これまで“協調ゲーム”が行われてきた が，いまや，それが困難になってきた。

4) 中東はじめその他の地域でも武力衝突や紛争がしきりに招こるようになった。

2.しかし, この一極体制は同時に多極体制である。その理由は極めて簡単で ある。アメリカのみが唯一の超大国となってしまったが，しかし，このアメリ カ一国の力をもってしては国際政治経済の流れをコントロールし, その経済 的・政治的安定を保持することができないからである。

ヨーロッパ共同体の基軸となる諸国，とくにフランス，ドイッ，イギリスの 三国と日本の協力がなければ，それは難しい。いいかえると，それらの国が加 
わる多極体制のもとでのみ国際社会の経済的・政治的安定が可能となる。 それがまさに新しい国際秩序である。

3. その秩序を支える原則はアメリカと西ヨーロッパが共通にもっている価 值,「共通の価值」である。その中核にあるものが，人権と自由と民主主義であ り，アメリカがこれまでつねに国際社会で主張してきた理念である。

その経済に拈ける表現が自由市場経済体制であり，その国際版である自由貿 易体制，いいかえると，財貨，サービス，資本の自由取引を原則とする体制で ある。その政治的表現が複数政党をもつ議会制民主主義体制である。この人 権・自由・民主主義といら西欧的価值は，アメリカの政策形成の基底にあっ て，その政策の正統性を裏づける基本要素の一つである。

しかし,アメリカの政策形成に拈ける基本要素にはもら一つの重要なものが ある。それはアメリカの国益である。ここでアメリカの国益とは, アメリカの 政治的・経済的覇権を保持, アメリカのマクロ経済的な利益およびアメリカ産 業とそこに雇用されている労働者の利益，このすべてを指している。

4.アメリカの政策は統合する世界と分裂する世界の双方にむけられる。分裂 する世界のなかでも, アメリカにとって重要な地域, それは旧ソ連社会主義圈 (中・東部ヨーロッパ, 旧ソ連) である。アメリカは, 周知のように, とくに, ロシア共和国に扮ける市場経済への移行を助けることに力を入れている。

もし市場経済への移行がうまくいかなかったら, ロシアは経済的・政治的混 乱に陥り, 場合によっては西欧的価值,「共通の価值」に敵対する政権がそこに 出現する恐れがある。もしそらいう事態になれば, アメリカにとっても, 西側 諸国にとってもきわめて憂慮すべき重大な結果が生じることになるかもしれな い—といらのが，ロシアに対するアメリカと西ヨーロッパ諸国の援助の論 理である。

しかし, 東ヨーロッパやその周辺の地域で混乱が生じた場合, その混乱の影 響を直接にらけるのは，いうまでもなく，西ヨーロッパ諸国であるから，そこ での主役は E Cが演じるべきものとなる。少なくとも, アメリカがはじめから 
主役になることはない。例光ば旧ユーゴスラビアの状況に対するアメリカの政 策姿勢がそれを示す。

したがって, アメリカにとって最大の関心事は, 最近まで超敵対国, 旧ソ 連，とくにロシアであって，その他の国ではない。それはロシアはこれまでに 二極体制の一方の極としてアメリカと敵対的な関係にあった覇権国，ソ連，を 継承した国であり，そのロシアの動きはアメリカの国益の今後の直接にかかわ りがあるからである。

5. 国際経済のなかで, 統合をもっともよく示している地域はいらまでもなく 西ヨーロッパである。ヨーロッパ共同体 E C は1992年に現実予定の共同市場， マーストリヒト条約など，結束が強まり，さらにE C 加盟国の増加など西ヨー ロッパは巨大経済圈への展望をもっている。やがて完成されるかもしれない巨 大経済圈には，アメリカを上回る生産能力を保持し，成長する可能性がある。 そして，その延長線上に，政治・経済の両面にわたる国際秩序のあり方に強い 発言力を発揮する「ヨーロッパ」のイメージがある。そして，その基底にある ものは, さきの西欧的価值の共有と同時に, ヨーロッパ中心主義の視角と行動 である。

東が消えたとき，E Cには二つの方向が可能であった。

(1) E C 統合の推進。

（2）全ヨーロッパを包括し，ゆるい連合体の形成へむけての転換。また，統 合は共同市場の段階まで。

しかし，現実は（1）のコースを進んできた。アメリカにとっては，ECの展 開のあり方が変わるとき，ヨーロッパとのかかわり方も変わる。ヨーロッパが しだいにアメリカから自立した方向へむからにつれて、ヨーロッパは国際経済 秩序のあり方に大きい影響力をもつようになる。それはヨーロッパとアメリカ の関わり合い方の変化を意味する。

しかし，ヨーロッパがぞのよらな方向へ進んでいくにしても，ヨーロッパに 拈けるアメリカの存在は影の薄いものとなる。極端な場合, アメリカの「居る 
場所」がなくなるよらなことが扣きるかも知れない。その䯚念は, 経済の領域 にも, 政治 (軍事) の領域にも，ともに存在する。

状況いかんによってECの要塞化が拈きれば，アメリカはヨーロッパ市場か らしめだされる。それは同時に自由貿易体制の崩壊につながる。これはアメリ カにとって簡単には認めるわけにはいかない事態である。

さらに, どのような方向へ事態がむからにせよ, 安全保障の視点から, 旧ソ 連を含をヨーロッパ地域のなかに，アメリカに敵対的な強力な国あるいはその 同盟の出現を認めるわ汭いかない。

6.上に述べたよらに，ヨーロッパは独自の途を歩んでいる。そのヨーロッパ と同じょうに, 日本もまたアメリカから自立した方向へむかって動きはじめて いる。これを，アメリカと対等のパートナーシップヘむけての動きとみ.ること もできるが，これはこれからの国際協調の難しさを示すもの，とみることもで きる。焦点を経済・貿易にしぼるとき，このことは明確になってくる。

すでに明らかなよらに，G79頻繁な会合にもかかわらず, 財政政策や金融 政策に打任る国際協調はいかにも難しくなってきている。また，ウルグアイ・ ラウンドの農業政策をめぐる交渉にしても，アメリカ， E C ，日本の間での主 張は大幅に食い違っている。とくに後者は自由貿易体制の保持と深く関わって いる。

したがって，ウルグアイ・ラウンドを妥結させること（決裂させないこと） はアメリカにとって大きい関心事である。農産物貿易をはじめとして, 知的所 有権, 紛争処理, セーフガード, サービス貿易, そのいずれもアメリカ産業に 強い利害関係のある重要な交渉項目である。それらの項目について理にかなっ た妥協がえられることは，自由貿易の原則にたつ国際経済秩序の視点からも， アメリカの国益の視点からも重要なことである。

7.しかし，ここでは注目すべきことは，アメリカは，いろんな事態にそなえ て多元的な現実政策とっているといらことである。したがって，ウルグアイ・ ラウンドがうまくいかなくなった場合にも，それに対応できるような政策をア 
メリカはとっているし，また，これからもそのための政策をとっていくであろ う。それはあくまでも, 自由貿易体制の確立・維持を射程のなかに招いての政 策である。

そこでの政策を貫く基本思想は相互主義である。自由貿易体制の保持のため に各国が市場開放や貿易政策に招いて協調的に行動するなら問題はない。しか し，それが難しいとするなら，相互主義の考光方に立った政策は有効となる。 いいかえると，それはゲーム論的に正当化される政策となる。相互主義に基づ くアメリカの政策は自由貿易体制の保持のために妥当なものとなる。

しかし，このアメリカの政策には，他の諸国に和ける根強い保護主義に対す る相互主義的な対抗策, 当該国に対して保護主義的政策の撤廃を求めるための 政策, とばかりはいえない要素がある。アメリカの政策形成のなかにしだいに 保護主義的な考方方が, 相互主義の名のもとに色濃く浸透してきているとみら れるからである。

たしかに，アメリカは国際経済社会に自由貿易体制を確立するために力をそ そぎ，みずからの市場を開放しつづけてきた。長い間, アメリカはグローバル な視点にたっての政策を実行してきた。しかし, 西ヨーロッパや日本の経済力 が強まり，アメリカとの格差が縮小してくるにしたがい, 競争力を失う産業が あらわれ，また，貿易・経常収支の不均衡が拡大するにともない，しだいに保 護主義化の色あいがその政策にでてくるよらになってきた。

いいかえると, アメリカの政策は, 一面では相互主義の視点を戦略に加え て，自由貿易体制を押し進めているが，他面では，それをと扢して保護主義的 な帰結を求めているといらことである。

8. 東アジア（東南アジアを含む）は世界経済の成長センターとなって扣り， そこに频のずと一つのまとまった経済領域が形づくられつつある。アメリカは ヨーロッパとの関係と同時に東アジアとの結びつきを重視している。

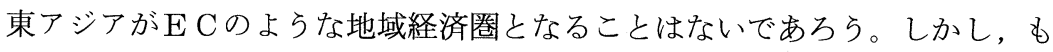
しそらいらことになれば，日本の大きい経済力のゆえに，そこでは中心的な役 
割を演じることになる。しかし，太平洋の彼方にあるアメリカは和のずとその 地域経済の「外」にたつことになる。日本が覇権的な立場にたっての経済圈が 生まれることにアメリカは決して賛成はしない。もちろん, 遠い将来は中国が 中心となるかも知れず，あるいはアジア太平洋国として対等の立場を主張して いるロシアが中心となるかも知れない。それでも, アメリカにとっては同じこ とである。

アメリカはアジア太平洋経済会議（APEC）を軸にした経済圏形成を望んで 扣り，アメリカやオーストラリアなど東アジア以外の国を除く経済圏の形成に 反対している。それは明らかにアメリカ経済の利益に反するからである。この ことは APEC の中にアメリカ大陸とオセアニアの諸国と東アジアの諸国を包 みこむことを意味している。いいかえると, アメリカは，より広大なアジア太 平洋経済圏の形成を, 重要な政策としていると，いらことである。

いらまでもなく，東アジアに和ける強国は中国，ロシア，日本である。その なかのいずれの経済的・政治的覇権を確立するようになることは，アメリカの 国益に反するとみている。したがって，そらした覇権国の出現を避けることに アメリカは強い関心をもっている。そして，その点に関するかぎり，中国，口 シア, 日本を除く東アジアの他の諸国とアメリカの間には共通の利益がある。 9.アメリカはその国益の追求を，できるかぎり「共通の価值」にもとづいた 「法と正義と」と両立しらるよらにしてきた。アメリカが国連, ガット，IMFな どの国際機関を利用してきたのはとのためである，といってよい。

アメリカがその国益と理想主義のバランスの上に追求していた政策は国際競 争力のあるアメリカ産業を基礎にしての自由貿易体制の保持であり, 強力なア メリカの政治・軍事力をバックにしての国際秩序の保持であった。それはアメ リカと利害関係のある地域の市場開放とアメリカに敵対的な経済力・政治的覇 権国の出現を阻止することであった。いまも，それには変化はない。しかし， もしアメリカ経済の地盤の相対的沈下がこれからも進むならば, アメリカは相 互主義といら名分を用いながら，みずからその保護主義的な政策を実行するで 
あろら。

また, ヨーロッパ中心主義に対応する形でのアメリカ中心主義に傾倒し, 国 際秩序の保持の負担を, 一方では, でさるかぎり圧縮しようとしながら, 他方 ではその利益を確保しようとするであろら。

こうして，その政策のなかから理想主義の色合いを急速に薄めていくことに なるであろら。

$\diamond コ メ ン ト \diamond$

日本大学 加藤 義喜

本報告で示された基本認識には，現在の世界経済リーダーシップが一極化の 中で多極化しているといら把握を含めて同意できるところは多いが，個々で私 が主としてコメントしたいと考えているのは次の二点である。第一には，渡部 報告は, 本報告の課題である統合と分解の間で摇れているとされる現在の世界 経済の中でアメリカがどのよらな政策をもっているかといらことに関連して， そのアメリカにシステマッティックにまとまった「政策」といえるものが本当 にあるのかどうかといら点について論じてみたい。第二には，やはり同じく世 界経済の統合と分解と絡んで重要な関連をもっていると思われる国民経済や地 域経済統合の捉え方について，私なりの考方を提示し，同報告に対するもら 一つの論点としたい。

まず第一の，現在のアメリカに混迷する現在の国際秩序を一定の方向づを もって導くようなシステマティックなアプローチが存在するかどらかといら点 に関してであるが, 報告者はアメリカにはとらした「ポリシー」が存在すると いら前提で報告されているよらに思える。しかし私は, 最近のアメリカの政策 はかなり場当り的で，極端にいえば支離隇裂とさえいえると考えている。それ は通商面の政策にもはっきりと見られ, アメリカはかつてのガットを中心とし たグローバル・アプローチに加壳て, リージョナル・アプローチとバイラテラ ル・アプローチをほとんどポリシー上の統制なきままに併用している感じであ る。 